\title{
Breech Extraction
}

National Cancer Institute

\section{Source}

National Cancer Institute. Breech Extraction. NCI Thesaurus. Code C114136.

The delivery of a breech-presenting fetus with that is manually pulled through the birth canal. 